\title{
Continuation, Attachment, and William Makepeace Thackeray
}

'Thackeray wallowed in it; Anthony Trollope lived on it'. ' The practice of writing new novels about old characters, G. K. Chesterton argued, betrays a lack of artistic and emotional discipline. Chesterton's study of Dickens distinguishes the novelist from his contemporaries such as Trollope and Thackeray because unlike them, Dickens demonstrates a serious commitment to form: he upholds 'the separation and unity of a work of art' and refuses the temptation of 'putting, as it were, after-words and appendices to [...] already finished portraits. ${ }^{2}$ Dickens is further to be praised for a willingness to kill his darlings, because 'although his heart must have often yearned backwards to the children of his fancy whose tale was already told [...] [characters] were dead for him after he had done the book; if he loved them as children, it was as dead and sanctified children'. ${ }^{3}$ For Chesterton, this restraint on both structural and personal fronts from revisiting former subjects meant Dickens 'never did yield at all to exactly that indiscretion or act of sentimentalism [...] Or rather he never did yield to it except here in this one case; the case of Master Humphrey's Clock". ${ }^{4}$ The familiar friends of Mr Pickwick and Sam Weller, last seen when The Pickwick Papers ended in I837, returned three years later to further adventures in Dickens's new periodical. Novelwriting, as we have seen, is often an art of exceptions.

Yet if Pickwick's return in I 840 was a lapse in Dickens's exception from an unfortunate contemporary practice ('everybody else did yield to it'), this case can be more simply restated: Master Humphrey's Clock typifies a broader trend in the mid-Victorian novel of 'introduc[ing] old characters into new stories'. James similarly alludes to Trollope's 'practice of carrying certain actors from one story to another', and moreover, constructs a genealogy of this literary habit 'which he may be said to have inherited from Thackeray, as Thackeray may have said to have borrowed it from Balzac'. ${ }^{6}$ In his study of Balzac, James again makes this connection: 
All [society] in Balzac's hands becomes an organic whole; it moves together; it has a pervasive life; the blood circulates through it; its parts are connected by sinuous arteries. We have seen in English literature, in two cases, a limited attempt to create a permanent stock, a standing fund, of characters. Thackeray has led a few of his admirable figures from one novel to another, and Mr. Trollope has deepened illusion for us by his repeated evocations of Bishop Proudie and Archdeacon Grantly. ${ }^{7}$

The biology of Chesterton's language, Trollope's living against Dickens's dead, becomes in James's the 'pervasive life' of characters who outstay the individual novel. But James's account also suggests a 'pervasive life' to novel practices, as authors borrow and pass on their habits much as 'the blood circulates' through a fictional society 'connected by sinuous arteries'. If, as Tillotson puts it, Thackeray 'takes pains to link his novels by the consanguinity of the personages' in series of long works which 'hang together like a dynasty', ${ }^{8}$ this is something Thackeray 'inherited' from Balzac's 'permanent stock', both in the commercial property sense implied by 'a standing fund' and also in the sense of 'a line of descent [...] a family or race'. ' In other words, the liveliness of characters in an organic world of relations is a family resemblance of the novel, a hereditary feature genetic to the form.

At the same time, 'life' represents another characteristic of fiction towards which the novel and its tradition bears a strongly ambivalent attitude. 'The Newcomes has life, as Les Trois Mousquetaires, as Tolstoi's Peace and War, have it', James writes in his preface to The Tragic Muse, 'There is life and life'. ${ }^{\text {Io }}$ In this passage, Thackeray's The Newcomes comes infamously to exemplify the 'large, loose, baggy monsters' of the nineteenth-century novel, possessing a pervasive liveliness which both characterises the novel and threatens its monstrous growth. ${ }^{\text {II }}$ Chesterton, too, singles out Thackeray's attachment to fictional lives as violating the novel's 'separation and unity', deforming the proper boundaries between his individual texts:

The habit of revising old characters is so strong in Thackeray that Vanity Fair, Pendennis, The Newcomes, and Philip are in one sense all one novel. Certainly the reader sometimes forgets which one of them he is reading [...] he cannot remember whether his favourite dialogue between Mr. and Mrs. Pendennis occurred in The Newcomes, or in Philip. Whenever two Thackeray characters in two Thackeray novels could by any possibility have been contemporary, Thackeray delights to connect them. $\mathrm{He}$ makes Major Pendennis nod to Dr. Firmin, and Colonel Newcome ask Major Dobbin to dinner. ${ }^{\mathrm{I}}$ 
Tillotson similarly notes how, although each of Thackeray's works has 'its own FINIS', we nonetheless 'cease to be much aware of differences, ceasing to attend to the chronology of the novels'. ${ }^{13}$ The habit of Thackeray's characters all to dine together, to sprawl out their social lives across multiple (each individually baggy) novels, exemplifies the 'organic whole' which James praised in Balzac as a feature of realist fiction. But such characters might therefore collapse the literary structure in which they reside, breaking down the novel form into a shapeless mass of homogenous experience.

This chapter reassesses the virtual lives of characters, the 'deepened illusion' of their persistence between and beyond individual texts, as a function of the novel's capacity for fictional worlds. ${ }^{14}$ In doing so, I defend 'wallow[ing]' and 'liv[ing] on' as legitimate modes of literary response, as well as critically useful methods of participatory interpretation. They provide another example of how Victorian novels produce meaning and pleasure through other means than as representations of life or finished artworks; and another instance of how these alternative uses of the form have been undervalued in criticism, but can be recovered as deliberate practices through their unembarrassed exemplifications in play. I develop Chesterton's and James's critiques while reversing their evaluative judgements: contextualising their observations about the appeal of fictional lives with Thackeray's own critical reflections, the reception history of serials and sequels, as well as autobiographical accounts from De Quincey, Brontë, and Trollope about the difficulty of leaving imaginary worlds. These perspectives together articulate the experience of attachment to fictions, what media psychologists describe as the development of a parasocial bond, as an alternative and underexamined sense of the what the novel is good for. In addition to providing vicarious experiences of power and possibility, and at odds with its other literary aims, the novel acts to sustain the imagined companionship of characters; a version of which is embryonic in, and can be more clearly understood through comparison to, the practice and narratives of the paracosm.

The Newcomes is my exemplary text for considering the novel's divided loyalties between its double roles as a literary and virtual object, affording two sometimes conflictual, sometimes cooperative forms of pleasure and interpretation. As critics have argued, the novel's narrative explores the lasting emotional effects of past relationships, refracting a central experience of loss and entanglement through multiple plots of widows, first loves, and second marriages. As I argue, however, the novel's fictional world also continually includes Thackeray's former characters from Vanity 
Fair and The History of Pendennis, embodying as a reading experience the inability to let go of finished relationships, or as Chesterton puts it, to bury 'dead and sanctified children'. ${ }^{\text {I5 }}$ The narrative's progress towards formal closure and thematic resolution, therefore, conversely intensifies the fictional experience of separation from a set of relationships cultivated through the long course of the serial text. Through this disjunction, Thackeray makes visible a tension between a literary work and its fictionality; opening a critical distinction which reveals other ways of using and valuing novels of this period.

\section{Novels for Life}

In an article for Fraser's Magazine in I846, facetiously addressed to Alexandre Dumas, Thackeray pitched a half-parodic, half-wishful set of 'Proposals for a Continuation of Ivanhoe'. Dumas would be right to reopen Walter Scott's historical novel, Thackeray argues, because Ivanhoe had in his opinion married the wrong heroine, choosing 'that icy, faultless, prim, niminy-piminy' Rowena over 'the tender and beautiful' Rebecca - but also because Scott had ended the original prematurely:

I, for my part, am one of the warmest admirers of the new system which you [Dumas] pursue in France with so much success - of the twentyvolume-novel system. I like continuations [...] and was never more delighted after getting through a dozen volumes of the Three Musketeers, than when Mr. Rolandi furnished me with another dozen of the continued history of the same heroes under the title of Vingt ans après [Twenty Years After]; and if one could get the lives of Athos, Porthos, and Aramis until they were I 20 years old, I am sure we should all read with pleasure. ${ }^{16}$

The presumption and infeasibility of these 'Proposals' is of course their deliberate comedic conceit, but they articulate a real (if wishful) form of literary response. While Thackeray is joking about his expectations, he is not feigning his earnest desire for an endless novel series, nor wrong to intuit Dumas's penchant for 'continuations'. In I 849, Thackeray wrote from Paris with 'intense delight' - perhaps more intense than when he 'was never more delighted' - about 'a novel called Le Vicomte de Bragelonne, a continuation of the famous Mousquetaires and just as interesting, keeping one panting from volume to volume, and longing for more'. ${ }^{17}$ Dumas's new novel, which carries the subtitle Dix ans plus tard (Ten Years Later) and ends with the death of two out of three musketeers, seems improbably to have vindicated Thackeray's earlier demand to 'get the lives of Athos, Porthos, and Aramis' in wholesale blocks of time. That he accidentally 
presaged this newest continuation, years before its appearance in print, suggests how his fantasies of Dumas were rooted in the objective qualities and narrative desires of the existing novels. 'I am sure we should all read with pleasure', Thackeray writes, in an evidently perceptive appraisal of what those pleasures are. ${ }^{18}$

The 'Proposals' are a flippant but honest expression about the powerful appeal of novel fictions - and the inevitable disappointment of novel texts. The publication of Dix ans plus tard exceeded Thackeray's expectations, but it could not exceed his fantasy. That his 'panting' through the new volumes (emphasising again the material size of the book) concludes with the open-endedness of his still 'longing for more' suggests how the desire for fiction is ultimately not exhaustible by the literary objects that spark them. Although a whole market of unauthorised D'Artagnan sequels emerged at the turn of the century, further justifying Thackeray's assessment of their givenness to continuation, no 'more' was forthcoming from Dumas himself. The impossible standards of the 'Proposals', only partially met by an already fortuitous reality, also anticipates this dissatisfaction: if the premise of the article is to extend Scott's Ivanhoe into something like Dumas's exemplarily long works, it quickly comes to desire an extension of the exemplar itself, with The Three Musketeers continued in batches of 'a dozen volumes' until its heroes 'were I 20 years old'. This scheme, which presumably sextuples the original 'twenty-volume-novel system', embodies a more general dissatisfaction than with any specific novel or ending. ${ }^{\text {I9 }}$ The 'Proposals' present a fantasy not yet realised in any precedent, not even those that surprise us with another (but still insufficient) dix ans.

What Thackeray wants from novels, and what novels cannot realistically provide, are their fictional 'lives'. Not the aesthetic arrangement of those lives, nor their meaningful explication, nor even their further adventures or dramas - he makes few demands to any of these - only their 'continued history'. Rather than any usual literary function, the 'Proposals' imagine using the novel primarily as a medium for staying in touch with its characters and world, for what Chesterton discerningly terms 'wallow [ing]' in fiction: 'To remain plunged in [...] sensuality, degraded habits', but also 'to be immersed or engrossed'. ${ }^{20}$ Such a desire is unreasonable, but hardly unusual: Gaskell makes a similarly formless and contentless appeal in her 'wish [that] Mr Trollope would go on writing Framley Parsonage for ever'; ${ }^{21}$ James's character Theodora 'should like [Daniel Deronda] to continue indefinitely, to keep coming out always, to be one of the regular things of life'; ${ }^{22}$ Tennyson has a strong 'dislike [for] beginning a new novel. I should like to have a novel to read in a million volumes, to last me 
my life'. ${ }^{23}$ Samuel Taylor Coleridge, deploring this kind of vacant absorption, refuses to 'compliment their pass-time, or rather kill-time, with the name of reading', comparing it instead to 'swinging, or swaying on a chair or gate; spitting over a bridge; smoking; snuff-taking; tête-à-tête quarrels after dinner between husband and wife [...] \&c. \&c. \&c'. ${ }^{24}$ If 'reading' implies a process of narrative attention, aesthetic judgement, critical interpretation, etc., 'readers' like Thackeray, Gaskell, Theodora, and Tennyson are engaged in different forms of relation to the literary object, which may indeed include passing or spending time in fiction. Or in another way of putting 'kill-time': living with the novel.

Practically, of course, novels cannot only provide the continued experience of their fictional worlds, but must also necessarily perform their more usual functions of telling a story, making expression, reflecting the real, or even fitting into a book, most of which contribute in some way to the appeal of that world in the first place. The novel may be the most available nineteenth-century cultural medium with which to - and the most inspiring of a longing to - 'live in a world altogether outside the world of my own material life' ( $A A 33$ ), especially by offering lives and worlds peculiarly compatible with those of its readers, and as we will see, by imaginatively sustaining them through the serial. Yet those testimonies which draw explicit attention to this feature of the form are also inherently expressions of disappointment: Ivanhoe, Daniel Deronda, and Framley Parsonage do not go on for 'a million volumes', even as they might recommend themselves to do so. If the novel is dependent on the printed volume or number as a medium for its reading experience, in their shared fantasies for a more impractical novel, readers like Thackeray make visible the disjunction as well as affordance between the novel's virtuality and its material or literary form. At stake in feeling the disappointment of novels for ourselves is a keener critical perception of what their contemporary readers and authors 'proposed' the form could do.

Perhaps the best, culminating case for exploring this disjunction is that of John Ruskin, who in a more earnest version of Thackeray's article, petitioned the novelist Henrietta Stannard for a kind of text she was clearly unable to deliver. ${ }^{25}$ In a public letter to The Daily Telegraph in 1888 , entitled 'Novels and their Endings', Ruskin laid out his vision for a novel he could live with:

[O]ne of the increasing discomforts of my old age, [is] never being allowed by novelists to stay long enough with people I like, after I once get acquainted with them [...] I felt this acutely the other day, when the author answered my quite tearful supplication to her, that Mignon and 
Lucy might not vanish in an instant into the regions of Praeterita and leave me desolate, by saying that [...] the public of to-day would never permit insistence on one conception beyond the conventionally established limits. To which distrust I would answer - and ask you [the Telegraph's editor], as the interpreter of widest public opinion, to confirm me in answering - that for readers even of our own impatient time [...] the highest praises of invention are in the recognised and natural growth of one living creation; and neither in shifting the scenes of fate as if they were lantern slides, nor in tearing down the trellises of our affections that we may train the branches elsewhere. $^{26}$

The novel, Ruskin argues, requires recognition for its appeal in sustaining the 'natural growth of one living creation', a formulation which echoes the 'pervasive life' and 'organic whole' James similarly identifies in Balzac's narrative world, but which is also metaleptically entangled with the life of the reader. ${ }^{27}$ It is not only the fiction that grows in this passage but also 'the trellises of our affections' with it, as well as the reader himself in his 'old age', both of which derive a sense of structure in the presence of fictions (as branches on a trellis), and are violently discomforted by their withdrawal at the end of the novel, stopping 'in an instant' what Tennyson (also in his final years) wishes 'to last me my life'. ${ }^{28}$ As Auyoung has similarly noted, readers can desire more of a novel 'not because of what happens in the narrative but because of the social separation imposed by its termination'. ${ }^{29}$ Again without any suggestions of narrative content or aesthetic intention, the desire simply to 'stay long enough with' fictions, not to be left stranded outside the imaginary 'regions' opened by the novel, is meaningful (even life-affirming) in itself.

What can we learn from looking at individuals' fantasies of novels - at satirical proposals, earnest supplications, and uncritical yearnings for continuation - rather than actual novels? For one: the alternative uses of the novel as a fictional world, occasioning real and meaningful experiences of the text without reference to its content or form. Ruskin helps to point out a conflict between alternative criteria for the novel, between what Stannard believes 'the public [...] would never permit' and what 'widest public opinion' (NE 605) might in fact support - as I have argued, this is a critical disagreement about the function and value of the form in which its fictionality has long been sidelined. As F. R. Leavis summarily appraised them in The Great Tradition, in Thackeray's novels 'the essential substance of interest [is] so limited that (though, of course, he provides incident and plot) for the reader it is merely a matter of going on and on [...] that time 
has been killed (which seems to be all that even some academic critics demand of a novel)'. ${ }^{30}$ Literary responses such as Ruskin's, Tennyson's, or Thackeray's own, by emphasising the novel's accompaniment to life, give examples for reassessing the significance and particularity of what fiction offers through its presence in time - as well as what criticism might (not quite so simply) demand from it on that score.

For another: we learn how a fictional world can deform its medium. Ultimately, Ruskin's attachment to certain fictional friends produced a strange distortion of the literary works in which they featured as characters. Only five months after his letter to The Telegraph, Stannard published Bootles' Children, a continuation of her three existing novels about the life of the foundling girl Mignon (Bootles' Baby in I 885, Mignon's Secret in I 886, and Mignon's Husband in I 887). In her preface to the new novel, Stannard acknowledges the necessity 'for me to give some word of explanation that, after bidding farewell to Bootles' Baby, I should continue the story', by responding almost directly to 'Novels and their Endings':

The truth is this - I received many letters asking me to show something of Mignon's later life, all of which made me wish with regret that I had not closed that page, as I thought, forever. But when my dear and honoured friend, Mr. Ruskin, said to me that he also would like to know more of Mignon, I felt that there was no more to be said, but that when the spirit moved me to do it, Mignon must go on the stage again.

There is not much about Mignon in this story, but there is a little that I hope will interest those who love her; and if there are some who are a little tired of her, well, I hope they will bear with her when they remember that this story was written in the hope of giving an hour's pleasure to one whose whole life has been to give delight and help wherever the English language is spoken. ${ }^{3 \mathrm{I}}$

The language of resistance and obligation recurs throughout this passage, which is riven with Stannard's self-consciousness about breaching 'the conventionally established limits' ( $N E$ 605) she had first protested to Ruskin. It is 'necessary' to explain herself to readers who will hopefully 'bear with her', but she has been 'moved [...] to do it' by Ruskin's request (other readers also make her 'wish with regret', but are insufficient to persuade her). At the same time, Stannard's preface is also apologetic to those who wanted the continuation: as there is really 'no more to be said' about Mignon's life, the novel produced specifically to say more about her finally has 'not much about Mignon' after all. Caught between bad form and readerly disappointment, Stannard's dilemma suggests how fictional objects can disrupt works of art, distending formal boundaries and 
unpicking narrative closures in order to 'stay long enough with people I like' ( $N E 605)$; and even in so doing, achieve not so much the 'natural growth of one living creation' (605) as the uncomfortable extension of an exhausted subject.

This is a more conflictual picture of the relationship between forms and fictionality than John Plotz presents in his survey of current criticism on the 'persistent features of Victorian-era worldmaking projects [...] larger than any single book'. ${ }^{32}$ As Plotz observes, reformulating and updating James's Theodora, literary studies on continuation are strongly grounded in the book or media history of serial formats:

This sensation of iterativeness, of repetition bound up with everydayness and both bound up with the format in which many Victorian novels first appeared - was long slighted in critical accounts of the 'age of the novel' [...] It's been a welcome development of recent times that scholars have drawn our attention to the role that such serialization played then - and its affinities to some of the roles that TV plays now. The everydayness and indefinite continuation of narrative (its non-evadable all-over aspect) pervasively shapes recent critical accounts[.] ${ }^{33}$

A critical account of Thackeray's 'Proposals' or Ruskin's 'tearful supplication' cannot but pervasively notice the Victorian desire for fiction 'to continue indefinitely, to keep coming out always, to be one of the regular things of life' ${ }^{34}$ Yet neither can it avoid their sense of frustration or disappointment with how 'the format in which many Victorian novels first appeared' in fact failed to accommodate this desire. ${ }^{35}$ If such readers felt their wishes for 'indefinite continuation' to be 'bound up' with format, they seem less likely to think of this boundedness in Plotz's intended sense of delivered through the serial format than restricted by material forms in general, as a set of 'established limits' ( $N E$ 605) which (to their dismay) puts practical brakes on the experience they want. To further distinguish the specificity of fictional experience, and its ambivalent place within the mixed purposes of the literary work, we need to examine how the novel's material forms attempt but fail to realise readers' desires for continuation.

\section{'Bound Up with the Format'}

Plotz's argument is informed by book history and media studies, specifically by their emphasis on the material shape and experience of the text as it arrived in the hands of historical readers. The particular advantage of this emphasis for studying serial works is that it recovers the physical divisions of parts, numbers, and instalments, and their attendant narrative rhythms 
and breaks over time - otherwise lost in their subsequent assimilation into a completed edition - which critics have argued as sustaining a distinctive reading experience. Holly Furneaux has suggested how 'the approaches recommended by book history, attentive to the conditions of publication' help critics to perceive a 'serial form in which linear, teleological reading is structurally discouraged and closure is only ever a temporary cessation'. ${ }^{36}$ For Ben Winyard, reconstructing the 'original format and rhythms of publication brings us closer to the work's initial modes, cadences, and temporalities [...] [and] gives us formal spaces or gaps in between instalments that encourage the proliferation of imaginative surpluses' ${ }^{37}$

The disadvantage of this focus on real, material texts is its occlusion of what historical readers may have found still incomplete or disappointing about literary objects. Theodora, whom Plotz quotes in epigraph, is wilfully blind to material conditions when she envisions her ideal Daniel Deronda as a hypothetically infinite version of Eliot's novel. Her wishful comments - like Tennyson's, Thackeray's, Gaskell's, or Ruskin's - are antitheses of book history, representing an approach of deliberate inattentiveness to the realities and exigencies of publication in their collective demands for the impossible: for million-volume novels, I20-year-old protagonists, and fictions without end. The insufficiency of any reading experience, including that of the serial (although it may go further than others), to realising the ongoing fictional life such readers desired is reflected in the variety of material formats in their accounts, all of which they can imagine expanding into continuations, from the expensive tripledecker of Ivanhoe, to the serialised D'Artagnan novels (which Thackeray read in collected volumes), and the single-volume Mignon novels (published annually). Yet such wishes clearly attend to something with real effects: Thackeray's unfeasible wish accurately anticipated Le Vicomte de Bragelonne, Ruskin's directly produced Bootles' Children, and Theodora's fantasy is reflected by the many unauthorised Daniel Deronda sequels that came to infuriate Eliot. ${ }^{38}$ That none of these cases really created an infinite novel (often creating very bad novels instead) does not mean they were not historically shaped by the optative, the historically unrealised version of themselves; the object in hand may be both a completed novel in itself and only a partial satisfaction of something else.

If, as book historians suggest, the serial format encouraged its readers 'to imagine more' than the sum of its parts, another way of putting this may be as a discrepancy between the material text and its imagined world. ${ }^{39}$ As we have seen with Trollope, a discontent with closure and the readiness of 'space or gaps' are not exclusive to the experience of the serial, but inherent 
to the novel's projection of an ever-growing fictional reality. ${ }^{40}$ As George Levine argues, 'realism, in its antiliterary preoccupation with the real', struggles to represent 'the monstrously shapeless and unattainable nature of ordinary reality' within any given literary work. ${ }^{4 \mathrm{I}} \mathrm{D}$. A. Miller observes how "'reality", or the realist text, unmoors [...] the anchors of traditional narrative' which conventionally maintain 'a well-policed periphery, where narratable potentialities are either nullified, reined in, or denied importance'. ${ }^{42}$ Whether it is an overflow of 'ordinary reality' or 'narratable potentialities', such critics agree that the novel can have divided loyalties between a tendency to experiential profusion and a commitment to other goals (aesthetic, moral, narrative, or commercial). If the novel's fictional experience is 'bound up' within its material conditions, this relationship may be one of bad fit, the imaginative potential of one chafing the necessary limits of the other.

Investigating the novel's 'everydayness' requires looking beyond seriality or continuation as material experiences of format, to the inherent capacity of fictional worlds to accumulate and engross. This experience and appeal of fiction, separate from (or even straining) narrative or form, is present even in those works Plotz cautions as the 'non-serial novel', works whose continuousness should not (he argues) be overstated above 'a distinctive formal disposition to center around one plot, one set of linked outcomes that are arrayed in a determinable relationship with one another and pegged towards the resolution'. ${ }^{43}$ Yet a reader's perverse desire to stay in a novel, even after the work is finished, can outweigh better judgements of form and meaning. John M. Picker, for instance, highlights the many unauthorised continuations to Daniel Deronda, realisations of Theodora's fantasy which as 'a sequel to an Eliot novel, in its very status as a sequel, misrepresents Eliot's aesthetic of realism'. ${ }^{44}$ Such presumptuous readerresponses almost unanimously reconvert Deronda back to Christianity, clearly misconstruing the narrative and moral values of Eliot's original text. But they also identify a different kind of value in the fictional lives of its characters, caring enough to continue them while leaving much else (more ostensibly significant) about the work behind.

Brontë's novels, with their original three-volume format and narrow focus, similarly reveal themselves to contain expansive fantasies of continuous fiction, a pervasive life which threatens to break out of narrative. As Elisha Cohn has argued, in Brontë's Villette, Lucy Snowe's recurrent daydreaming 'misrepresents and distracts from the plotted - that is, moralized - experience', pausing the development towards resolution to offer a 'moment of non-closure, projecting the pleasure of suspended 
animation outward toward the reader'. ${ }^{45}$ For Cohn, these moments of 'still life' represent instances of lyrical reflection embedded within novelistic narrative, but the imaginative practices of Brontë's protagonists are often not so much still as agitated, turning circles in one spot or 'swaying on a chair or gate'. ${ }^{46}$ Unwilling to seek adventure, Lucy claims to 'hold two lives - the life of thought, and that of reality', each bespeaking not so much reflection as sustenance, not still life but pass-time: 'the former was nourished with a sufficiency of the strange necromantic joys of fancy [...] the latter might remain limited to daily bread, hourly work, and a roof of shelter' ${ }^{47}$ Newly arrived and restless at Thornfield, Jane finds it a relief to pace the third storey 'and, best of all, to open my inward ear to a tale that was never ended - a tale my imagination created, and narrated continuously; quickened with all of incident, life, fire, feeling, that I desired and had not in my actual existence' ( $J E$ I 32). What the young Jane narrates internally is a distraction from the bildungsroman being narrated by the older Jane, a continuous provision of imagined experience rather than the plotted course of the novel. In sharp contrast to the tale of her 'actual existence', which progresses teleologically from childhood towards marriage, Jane walks 'backwards and forwards' (I32) along the corridor while imagining her 'quickened' and 'never ended' story. Speeding continuously towards no destination, Brontë's protagonists enact serial desires within their distinctively non-serial narratives, imagining fictions which fill up the empty time of their lives.

All realist novels contain the desire or potential to continue - whatever their material format or narrative appropriateness - because they imagine fictional worlds, and worlds are not read, nor communicated, nor published but inhabited, departed from, and ongoing. Brontë's mise-en-abymes express these forms of relation in the midst of a material medium both suited and unsuited to them, but also gestures to the biographical practice where such experiences took precedent over writing's other uses - in play. The continuous narrative of 'incident, life, fire, feeling' ( $J E_{\text {I }} 32$ ) with which Jane amuses herself is an exact characterisation of the sprawling narratives of the Brontë juvenilia. As Brown puts it, "the Angrian plot is "never-ending": contingent rather than causal, episodic rather than progressive, without impediment to desire and without principle of closure'. ${ }^{8}$ I argued earlier that the world of the juvenilia is a space for fictional wish-fulfilment, where desires about fictions can be realised without the constraints or responsibilities of the professional novelist. Here, it becomes a space for realising the desire for fictional living - the lives of characters can occupy their creators 
for decades of play, because they are exempt from such exigencies as literary meaning, material format, and commercial pressure.

The fantasy which Thackeray and Ruskin struggled to make real, stretching the 'conventionally established limits' (NE 605) of the adult literary market, finds an ideal format in the impossible, unreasonable, and childish world of the paracosm. Social scientists such as Cohen, MacKeith, and Root-Bernstein emphasise the distinctiveness of imaginative play which involves 'the consistent return [...] to a specific scenario, as evidenced by the naming of place and characters or the elaboration of a continuous narrative'. ${ }^{49}$ Nineteenth-century accounts too stress the pleasure and significance of this persistence, even to the point of apprehensiveness, about how long children (and eventually, adults) go on imagining one creation. As we have seen, Jameson's play lasted 'from ten years old to fourteen or fifteen', ${ }^{\text {so }}$ while Trollope carried on developing the same tale 'for six or seven years before I went to the Post Office, and was by no means abandoned when I commenced my work' ( $A A$ 33). Derwent Coleridge writes of Hartley that 'if the early age in which this power was exercised be remarkable, the late period to which it was continued was not less so. I have reason to believe that he continued the habit mentally, from time to time, after he left school' ( $H C$ xlv). As Shuttleworth observes, the underlying anxiety in these accounts - that paracosmic play went on too long, extending inappropriately into adulthood and professional life disturbed nineteenth-century psychologists as a potential 'disturbance of natural rhythms'. ${ }^{5 I}$ We will encounter more of such cultural-medical anxieties in the next chapter, particularly around the case of Hartley, in order to theorise the period's debates about the psychological nature of fictions.

Here, however, what play again enables us to understand about the novel is its distinctive pleasures and qualities as a medium for fiction, which we might otherwise evaluate as aspects of its materiality or literariness. Play reveals the burgeoning fictional world inside of and discontenting the literary work, modelling the intense attachments and relations such worlds cultivate in tension with aims of artistic separateness or ethical disinterest. Can these divided goals be reconciled? How can we perceive the novel as a form of compromise? As I argue, these are questions authors themselves confront on the borders between fiction and literature. By investigating instances of fiction's explicit discontinuation, I examine what it means to cut off the worlds of play and the novel - what novelists such as Brontë, Trollope, and Thackeray found both necessary and painful about such departures, and how a longing for 
the fictional world registers in their writings of closure as a formal distention or lingering.

\section{Farewell to Angria}

Children are often articulate about the importance of their possessions, and particularly of their creations; the unwillingness of play to surrender an entire imaginary world is an extravagant example of this tendency. As Root-Bernstein argues, worldplay requires 'that the child value the play highly $[. .$.$] the paracosm had to satisfy certain emotional or intellectual$ needs; it had to "matter"'.52 As we have seen, De Quincey's commitment to the persistence of imaginary worlds extended even to those of others, leading him to imagine the state of things in Ejuxria after Hartley Coleridge's death. For himself, sustaining the reality of Gombroon mattered to the point of transforming the relationship between creator and creation into a set of 'contracted obligations [...] submitting my conscience to a yoke' $(A S 47)$, even when the game turned sour from repeated assaults by his older brother:

Still there was one resource: if I 'didn't like it', meaning the state of things in Gombroon, I might 'abdicate'. Yes, I knew that. I might abdicate; and, once having cut the connection between myself and the poor abject islanders, I might seem to have no further interest in the degradation that affected them [...] but this connection with my poor subjects had grown up so slowly and so genially, in the midst of struggles so constant against the encroachments of my brother and his rascally people; we had suffered so much together; and the filaments connecting them with my heart were so aerially fine and fantastic, but for that reason so inseverable, that I abated nothing my anxiety on their account[.] (53)

It would be more appropriate to characterise De Quincey's play as a need for continuation rather than a desire, as the affective attachment between him and his own fictions - the 'obligations' of care, the 'yoke' (47) on his conscience - becomes coercive or masochistic in its hold. Maintaining 'further interest' (53) in his defeated peoples only further perpetuates his and their abjection in a game he cannot nonetheless give up, in an example of what Lauren Berlant has called 'cruel optimism', 'a relation of attachment to compromised conditions of possibility [...] whatever the content of the attachment', a more dispiriting version of Root-Bernstein's sense that paracosms 'satisfy certain emotional or intellectual needs'. ${ }^{53}$ 
Without suggesting that all (or even most) attachments to play's fictions are cruel in this way, De Quincey's account is a useful model for the bonds between fiction and reader that drive the desire for continuation. In the novel, something like De Quincey's 'connection' to his islanders clearly underlies Ruskin's explicit emotional need to 'stay long enough with people I like' ( $N E$ 605), where longer is never enough. His resistance to changing one fiction for another 'as if they were lantern slides' (605), as well as Tennyson's to 'beginning a new novel', ${ }^{54}$ flinches from the kind of separation De Quincey avoids in refusing to 'cut the connection' ( $\left.A S{ }_{53}\right)$ between himself and the paracosm (and presumably, start anew with less harrowed characters). The concept of 'Praeterita', the 'regions' (NE 605) into which Ruskin imagines characters receding after the narrative, explicitly imagines the fiction as a world from which one has become inseverable' $(A S 53)$. Like the serial reader, the paracosmic player too deploys the metaphor of the organic tie, a sense of form for which interruption entails pain: for De Quincey, the 'filaments connecting [Gombroon] with my heart'; for Ruskin, the 'natural growth of one living creation' supported by and entwined with 'the trellises of our affection' ( $N E 605)$. This connection is an effect of time, of having 'grown up so slowly and so genially' $(A S$ 53) or become 'acquainted' ( $N E 605)$, but is now also the living structure which keeps it growing 'beyond the conventionally established limits' (605), supplanting literary form or publication format as the ideal structuring principle of the novel. Like Theodora - wishing for fiction to be 'part of one's life; one lives in it, or alongside of it' - they petition for novel fictions which ornament, structure, and fill in the gaps of actual life, for a relationship where 'the continuity of its form provides something of the continuity of the subject's sense of what it means to keep on living on'. ${ }^{55}$

In using the novel as a medium or habitat (as a vine does a trellis), fictional worlds produce literary effects and distortions precisely through their distinction from the literary text. Defending Pickwick's reappearance in Master Humphrey's Clock, Dickens argued that he 'revived Mr Pickwick and his humble friends; not with any intention of reopening an exhausted and abandoned mine, but to connect them in the thoughts of those whose favourites they had been, with the tranquil enjoyments of Master Humphrey'. ${ }^{56}$ The deceptively simple infinitive clause combines two actions of socialisation - connecting Humphrey and Pickwick as fellow members of a storytelling club, a relationship in the narrative world, and Pickwick having been a favourite of readers, a metaleptic relationship - in the service of creating a new loyalty between readers and 'the tranquil enjoyments of Master Humphrey'. It is of course disingenuous to imply 
that a scheme to familiarise old readers with a new periodical is not also economically motivated, but as Holly Furneaux points out, such a strategy is both 'conceptually coherent as well as commercially astute', designed to imbue the new narrative with 'a sense of continuation, as characters, never wholly tied to the text in which they (first) appear, have an ongoing imaginative currency for regular readers [...] eager to foster relationships of long gestation through many instalments by incorporating fictional characters into their own social circle'. ${ }^{57}$ Dickens's comments implicitly acknowledge that the logical flipside to this 'sense of continuation' is a resistance to discontinuation - as Ruskin observes, to the unnatural act of suddenly exchanging one set of acquaintances for another - which can only be overcome by strenuously connecting the old with the new. Yet as Dickens's defensiveness shows - not 'reopening an exhausted and abandoned mine' - and as Chesterton subsequently argues, familiarity is at once a draw for readers and a literary failing. For Stannard, likewise, a consolatory reunion with Mignon is an infringement on the public responsibilities of authorship, requiring justification for those 'who are a little tired of her..$^{58}$

Such guilt about returning to the imagined world, yet the pain of leaving it behind, models the inherent conflict between the novel's fictional and literary functions. In I 839, after thirteen years of playing and writing her imaginary world, but still eight years before the publication of Jane Eyre, Brontë encountered this conflict as a point of transition between two biographical phases of her authorship. In the untitled autobiographical fragment which critics evocatively call 'Farewell to Angria', Brontë claims to 'have now written a great many books, $\&$ for a long time I have dwelt on the same characters $\&$ scenes $\&$ subjects'. ${ }^{59}$ In its first paragraph, Brontë describes a creative exhaustion radically at odds with our canonical sense of where her literary career begins:

I have shewn my landscapes in every variety of shade \& light which morning, noon $\&$ evening - the rising, the meridian $\&$ the setting sun can bestow upon them [...] So it is with persons - my readers have been habituated to one set of features, which they have seen now in profile now in full-face $[\ldots]$ with the round outline of childhood, the beauty $\&$ fullness of youth, the strength of manhood $\&$ the furrow of thoughtful decline. But we must change, for the eye is tired of the picture so oft recurring $\&$ now so familiar. (FA 3 I 4 )

Cyclical and developmental time combine in this descriptive time-lapse, running both the 'familiar' face of the character through the linear progression of age and the Angrian environment through 'recurring' daily and 
seasonal changes, the two terminating together with the need for 'change'. The dual timescales suggest perhaps how the indefinite accumulations of successive Angrian plots ('a great many books') have finally become repetitive iterations of each other, like Jane Eyre walking 'backwards and forwards' in her daydream of 'a tale that was never ended - a tale my imagination created, and narrated continuously' (JE I32). It may also reflect how the increasing inevitability of change ultimately builds up to an arbitrary point of termination - the juvenilia having no overarching plot or structure for closure, it seemingly ends midway (in a circle, every point is midway).

Yet if the first paragraph of 'Farewell to Angria' expresses a tiredness of paracosmic subject and practice, a development from the solipsistic neverending tale towards the published three-decker novel, the second paragraph acknowledges the difficulty of such a move. The same temporal force that exhausts a fiction also creates its familiarity and attachment:

Yet do not urge me too fast reader - it is no easy thing to dismiss from my imagination the images which have filled it so long. They were my friends $\&$ my intimate acquaintances \& I could with little labour describe to you the faces, the voices, the actions, of those who peopled my thoughts by day $\&$ not seldom stole strangely even into my dreams by night. When I depart from these I feel almost as if I stood on the threshold of a home \& were bidding farewell to its inmates. When I but strive to conjure up new inmates, I feel as if I had got into a distant country where every face was unknown $\&$ the character of all the population an enigma which it would take much study to comprehend \& much talent to expound. (FA 3 I4)

A different kind of time overtakes this second paragraph, transforming the unstoppable natural progressions of ageing and the sun to the more malleable speeds of human effort, reluctance, and urging. Associations of exhaustion reverse, turning the 'tired' subjects of the previous paragraph into ones which also require 'little labour' compared with new subjects which conversely 'would take much study'; not continuing the paracosm is a departure from an imagined space both 'familiar' and 'a home', a parting with characters too 'recurring' but also 'my friends \& my intimate acquaintances' (3 I4). Brontë's 'Yet' is not simply feeble protest but an argumentative turn, revealing the same reasons which make new fictions necessary as also those that make the discontinuation of old fictions difficult.

'Farewell to Angria' is the antithesis to Thackeray's speculations about literary continuation, not only because it gives up one set of fictions for another, marking the end of continuation rather than a hypothetical start, 
but also because it is apologetic about the very desires the 'Proposals' express. Autobiographically, 'Farewell' represents a point at which Brontë was seriously considering how to transition from play to work, or how to harness her already voluminous writing into a professional practice and into literary products. Whereas Thackeray's article suggests to us what the novel could be (for one, materially impossible) if it were fully to realise its fictional potential, Brontë's note identifies the painful distancing from fiction necessary for there to be a material novel.

Such apologetics exemplify a broader anxiety among Victorian novelists about the limited allowances of the form (and their grave discomfort with this limitation) for the desire 'to deepen ties to [an] imagined world'. ${ }^{60}$ In I 867, Trollope published The Last Chronicle of Barset, the final of a sixnovel series that began with The Warden in I855. After twelve years of writing about the same county - albeit switching his focus between an ever expanding network of characters each time - the end of this novel is also the end of a long relationship:

And now, if the reader will allow me to seize him affectionately by the arm, we will together take our last farewell of Barset and of the towers of Barchester. I may not venture to say to him that, in this country, he and I together have wandered often through the country lanes [...] I may not boast that any beside myself have so realised the place, and the people, and the facts, as to make such reminiscences possible as those which I should attempt to evoke by an appeal to perfect fellowship. But to me Barset has been a real county, and its city a real city, and the spires and towers have been before my eyes, and the voices of the people are known to my ears, and the pavement of the city ways are familiar to my footsteps. To them all I now say farewell. That I have been induced to wander among them too long by my love of old friendships, and by the sweetness of old faces, is a fault for which I may perhaps be more readily forgiven, when I repeat, with some solemnity of assurance, the promise made in my title, that this shall be the last chronicle of Barset. (LCB 727-28)

Trollope's 'last farewell' is concerned throughout with what he may or 'may not' do, or what he supposes the reader will or will not allow him. Although the passage begins with a positive request to 'seize [the reader] affectionately by the arm', Trollope imagines that the reader has not 'wandered often through' Barsetshire, and has not 'so realised the place, and the people [...] as to make reminiscences possible' (727) - but might forgive him for having done so. Like Brontë, who also assumes that her reader is urging her from her imaginary country, from 'the faces, the voices, the actions' (FA 3 I4) of her characters, Trollope apologises for 
how 'the voices of the people are known to my ears', for how 'old friendships, and [...] the sweetness of old faces' has perhaps led him 'to wander among them too long' ( $L C B$ 728). Both writers seem conscious of having committed a 'fault', of having indulged a selfish love of their own characters over their relationship with the reader. Trollope seems to feel he has dragged us somewhere only he expects to be able to go: 'But to me Barset has been a real county' $(728)$ - to us, presumably, it has only been a literary setting. The recurrent language of permission and apology in these farewells, and the 'promise' to take responsibility and write an ending at last, suggests finally that disjunction between public expectation and private desire, between the novel and its fictions, also visible in photonegative form in proposals and supplications for continuation.

The arm that we may or may not have linked with Trollope's raises the question of whether fiction's intimate attachments and familiarities, its friendships and its homeliness, are shareable through a professional literary work. Is the desire to continually spend time with certain characters inherently at odds with the form and function of the nineteenth-century novel? If so, how is the novel shaped (or distorted) by the competing demands of its fictionality with its literariness? The next section investigates these questions through Thackeray's own novels, which attempt to reconcile the sensation of indefinite ongoingness with the production of realist narratives. In writing The Adventures of Philip, he privately admitted that 'I can repeat old things in a pleasant way, but I have nothing fresh to say', conceding to the imagined indictment which agonised Brontë, Trollope, and Stannard. ${ }^{61}$ In The Newcomes, he deliberately evokes these dual experiences of staleness and freshness as contending thematic forces in a novel sequel about past relationships, finished adventures, and 'old things'. Engaged in the same, contradictory quest to produce literary works and to stay in fictional worlds, Thackeray's continuation can be read as an extended version of his 'Proposals': a practical experiment on how far our desires for fiction can be feasibly met by the novel. 


\section{THE NEWCOMES}

In I9I 2, the editor and critic Amy Barter arranged and produced a volume entitled Stories of Pendennis and the Charterhouse from Thackeray. Barter's book contributed to a series published by George G. Harrap and Company that repackaged canonical narratives for young readers - alongside titles like J. Walker McSpadden's Stories from Chaucer (I907) and Thomas Carter's Shakespeare's Stories of the English Kings (I9I2), Barter also later produced Stories from George Eliot (1913). Her instalment on Thackeray, however, is distinctive for being an anthology rather than an abridgement, departing from the series' convention of retelling or summarising plot, character, and appropriate moral in favour of a more thematic, even geographical, focus in its material. Potentially because Thackeray's novels are simply too expansive to retell, or in order to appeal to its school-going audience, Stories of Pendennis extracts only those chapters from The History of Pendennis, The Newcomes, and The Adventures of Philip which prominently feature Grey Friars, the central London public school attended by the protagonists of all three novels. The first four chapters of the book excerpt the schooldays of four characters in order of their matriculation: 'Thomas Newcome', 'Arthur Pendennis', 'Clive Newcome', and 'Philip Firmin'; the fifth chapter, 'Old Boys', takes two passages from The Newcomes in which alumni encounter each other in the world and reminisce about the school; and the sixth chapter, 'The Poor Brother', extracts Colonel Thomas Newcome's return to the school as a hospital pensioner, and his eventual death there. ${ }^{62}$ As much as Barter's arrangement hints at the publication order of the novels, it also reshuffles them (The Newcomes in particular) to more closely follow the fictional timeline of the narratives, and to form a thematic progression from schoolboy to alumnus to pensioner. The profusion of plots and characters excluded by this selective focus (most significantly, the novels' women) are relegated to the endnotes, which briefly explain the relation of characters to each novel and to each other.

Barter's selection and rearrangement of the novels model a radical alternative to reading them as individual literary works, prioritising a bond to location and homosocial tradition over narrative or interpretation. The excerpts are prefaced by an introduction in which Barter provides both a meticulous history of the real Charterhouse School on which the fictional Grey Friars is based, and a narrativised account of Thackeray's schooldays there, drawn from autobiographical and contemporary sources. This introduction is analogous to the excerpts themselves, 
especially in the context of Barter's habit to treat the real Charterhouse interchangeably with the fictional Grey Friars, as if Thackeray were himself one of his protagonists and his biographical experiences one more excerpt among the fictional ones that follow. The structure of Barter's anthology not only suggests the lifecycle in which Thackeray and his protagonists enter, leave, and return to Grey Friars but also how the reader returns, with increasingly familiarity, to a known and knowable location over time and across multiple novels. Moreover, the premise of her anthology itself suggests how these fictional visits can be isolated for enjoyment from the chaotic background of other plots, pleasures, and functions also active in a literary work. If, as Leah Price has argued, anthologies represent a view of the novel as islands of lyric or didactic or sententious collectibles bobbing up occasionally from a sea of dispensable narrative', what Barter fishes out from the vast ocean of Thackeray's novels are neither moral nor aesthetic but nostalgic and personal, the souvenirs of a set of relationships between Thackeray, his protagonists, his readers, and a (semi-fictional) school. ${ }^{63}$

Gathered together and freed from their functional role as bildungsroman backdrop, the prose 'collectibles' of Grey Friars create a sense of the school's independent fictionality as a setting, of its broader existence and autonomous future beyond literary representation. In a lengthy passage at the end of her introduction, Barter dispenses not only with the narratives and characters outside the school but with Thackeray's novels altogether, loosening the already attenuated connection between anthology and text to depart, wholly and imaginatively, into continuation:

We are sure that Arthur Pendennis, Clive Newcome, and Philip Firmin kept up the custom which had long prevailed in their families of 'sending their sons from generation to generation to the old school'. We are confident that Clive's son, Tommy, went there, and was a big boy and a monitor when little Arthur Pendennis arrived [...] that Tommy patronised and protected Arthur, and had much joy in thus reversing the relative positions held by a Newcome and a Pendennis a generation before; that Arthur, in his turn, patronised his own small brothers, who soon began to appear, one by one, at the bottom of the school, and tried to patronise a flaxen-haired, chubby little boy, who came with, let us say, the third Pendennis, and was named Philip Firmin [...] Further, by the help of the last paragraph of 'The Adventures of Philip' (in which Mr Pendennis tells of 'the great gathering the other day at Roehampton, at house of our friend Clive Newcome, whose tall boy, my wife says, was very attentive to our Helen'), we can see pupils of yet another generation, sons of a Newcome and a Pendennis, within the walls of the old school. ${ }^{64}$ 
If Barter's excerpts reorganise Thackeray's novels into a series of pleasurable return visits to Grey Friars, this passage engineers that pleasure to be pervasively self-replicating beyond even the end of his final novel, Philip. The children of the three protagonists enter the school in switched positions and recombinations, endlessly 'reversing the relative positions' and reappearing 'one by one, at the bottom of the school' in new generations of old characters. (Even the names repeat: besides Arthur junior and Philip the second, Helen is named after Pendennis's mother, and Tommy after Colonel Newcome.) Barter's repeated assurances that 'We are sure [...] We are confident' ward off and reveal the unspoken anxiety about finally leaving the familiar fictional space within the enclosed 'walls of the old school' - the type of space Brontë calls 'a home' shared with 'intimate acquaintances', or more troublingly, with 'inmates' ( $F A_{3}$ I $_{4}$ ). Barter's turn to futurity represents Grey Friars' final emancipation as a fiction from the contexts of narrative and novel. On the other hand, its new, independent unreality (its free-standing virtuality) seems to realise Trollope's fear that the reality and 'old friendships' of such places are sustained only by the retreading of old ground ( $L C B 728)$.

Barter's continuation takes clear cues from Thackeray's texts, responding to inherent desires in his fiction, much as Thackeray himself once responded to similar qualities in Dumas. Stories of Pendennis explicitly spins out a future from 'the custom which had long prevailed' in the novels and 'by the help' of direct quotations from them. ${ }^{65}$ It is surprising, in fact, that Barter does not mention how the final paragraph of Philip from which she quotes also jokes that 'The mothers in Philip's household and mine [Pendennis's] have already made a match between our children', suggesting not only Barter's speculative NewcomePendennis heir but also a future Firmin-Pendennis, and moreover, how the party 'having been educated at the same school [...] sat ever so long at dessert, telling old stories'; both reflections on Thackeray's creative tendencies that pre-empt Barter's later response. ${ }^{66}$ Her liberation of Grey Friars into its own, sovereign paracosm reflects how Thackeray's novels lend themselves to a paradoxical experience of fictional nostalgia and continuation, to a form of literary appreciation where satisfaction accrues onto 'old things' through the course of ever more familiar relationships, and finally, to a sense that these relationships and things outgrow the narrative text. Accounting for our evolving attachments to characters or settings is significant both because they arise from novels, prompting questions of how textual mechanisms encourage real relationships to fictional objects, and because they so 
often work against the more strictly literary (formal, narrative, moral, and practical) goals of the novel.

This section uses Thackeray's The Newcomes to examine this conflict between affective attachments to fictions and literary commitments to convention and form. I foreground The Newcomes over the three other novels that share its characters, history, and world - Vanity Fair, Pendennis, and Philip - first because it most exemplifies the features of continuation that run throughout the series, making the most intertextual connections to Thackeray's oeuvre of any work in his oeuvre. Secondly, the nature and experience of attachment is a central theme of The Newcomes, which (as its title suggests) models its multiple yet closely entangled plots after the estranged but inescapably related branches of the Newcome family. Finally, The Newcomes occupies an emblematic position within the critical history of the novel form, now perhaps best known for its reputation as the original English example of James's nineteenth-century 'baggy monsters' - alongside Tolstoy's War and Peace and (what would have delighted Thackeray) Dumas's The Three Musketeers. This account of the novel enables a reassessment of its formal bagginess as a function of its narrative and reading experience - both concerned with the weight of emotional baggage - and suggests a new analysis of form in general as part of the concretised experience of fiction. By investigating The Newcomes as a site of contestation between fiction and form, I seek to describe their competing demands in terms of physical tension, and more specifically, of elasticity: how they pull, distend, and resist each other, how they cling, stretch - and snap.

\section{Clinginess in the Family Network}

The Newcomes, family and novel, begins with an originary Thomas Newcome whose two marriages form the root of the narrative's elaborate family tree, plot structure, and thematic pattern. Arriving in London 'on a wagon, which landed him and some bales of cloth, all his fortune, in Bishopsgate Street', this ancestral Newcome makes his fortune in a cloth and banking business, and marries twice. ${ }^{67}$ First, his penniless betrothed from his native village, who dies giving birth to (the later Colonel) Thomas Newcome Jr.; and 'en seconds noces' ( $N C \mathrm{I}_{1} 8$ ), his employer's wealthy daughter, who bears him the twin sons Hobson and Brian Newcome ('called after their uncle and late grandfather, whose name and rank they were destined to perpetuate', 26). The Colonel himself comes to have two love-affairs: with his French tutor's daughter Mademoiselle du Blois, who 
is forced into a more convenient marriage, the heartbreak of which alienates him from his family and drives him to India; and then with the widow Emma Honeyman, who dies after marrying the Colonel and giving birth to Clive Newcome, the novel's protagonist. The twins produce a number of step-cousins for Clive, most of whom only occasionally surface in the novel, but Brian in particular (married into the aristocracy) begets Ethel and Barnes Newcome, the heroine and villain respectively.

Stripping the novel down to this abstract (and not too enthralling) genealogy reveals, even in the pre-narrative, its preoccupation with patterns of moral behaviour that replicate through generations of characters. Nicholas Dames has noted, after the contemporary reviewer James Hannay, that the original Thomas Newcome's marriages are 'neatly allegorical, one a love match (which produces the Colonel) and one a money match (which produces the novel's least morally admirable characters)' ${ }^{68}$ Characters throughout the novel, especially but not only the Newcome offspring, are recurrently presented with the same choice between a difficult marriage of love and a more indifferent marriage of convenience: Clive chooses between his beloved Ethel and the merely pleasant Rosie, Ethel between struggling painter Clive and a host of aristocratic suitors, Barnes between a villager he has impregnated and the respectable Lady Clara Pulleyn, Clara between her impoverished sweetheart Belsize and the wealthy but abusive Barnes - among other examples. As Juliet McMaster has also argued, 'the repetition of the mercenary marriage between various couples and its outcome is a unifying structural principle [...] The Newcomes is a set of variations on this theme'. ${ }^{69}$

But this often-noted structuring principle extends its logic beyond the consistent moral dichotomy of marriage choice. For instance, Clive, his father, and his grandfather share not only a doubling of partners but also the early deaths of their wives (who often themselves have chosen between, or survived to have, two husbands), just as Hobson and Brian's names, ranks, and even destinies explicitly echo forebears from their maternal line. As these relationship patterns replicate down the generations, the central plot of the novel can also be seen as a series of horizontal rearrangements as the potential match between Ethel and Clive rises and recedes in probability over their lives, as they meet and separate, fight and reconcile, engage or marry others and break off or are widowed, the branches of the Newcome family they represent also oscillate between intimacy, estrangement, and outright hostility. The Newcomes can therefore be characterised as an intersection of three narrative directions: the generational reproduction of an ancestral marriage plot, which increasingly divides and splinters 
the family tree; the novel's particular and focal marriage plot between its protagonists, which seeks to reintegrate the branches; and the picaresque chronicling of what Dames calls the novel's 'minutiae', the fine-grained experience of which hides the 'thematic architecture' of an at-once expansive and detailed novel behind the characters' day-to-day lives. ${ }^{70}$

Such a reading of the novel borrows its method from Caroline Levine's recent, 'new formalist' reading of Bleak House as 'using narrative form to work through the dynamic unfolding of kinship networks over time' - as apt a description of The Newcomes as any - but with a characteristically Thackerayan focus on time as a regulator (rather than facilitator) of connection. ${ }^{7 \mathrm{I}}$ Taking Bleak House's thrice-married Mrs Badger as an example, Levine argues:

As anyone who has ever tried to make a genealogical chart will know, the family is never graspable as a whole. It stretches indefinitely across time and space. Distant branches connect ever outwards, as marriages creates links to other families, old generations stretch back into the past indefinitely, and generations yet to come will continue to add nodes. And as Mrs. Badger suggests, the nodes of the family network are best figured as positions that can be endlessly emptied and refilled: new people supplant previous husbands and wives [...] nodes repeatedly replace themselves, and in doing so replicate the network in ways that stretch the institution of the family itself across time. ${ }^{72}$

The Newcomes' textual version of the genealogical chart, and Barter's later elaboration of its logic, both amply demonstrate a sympathy to this view of the family as network, but Thackeray's novel also requires us to modify Levine's model in two major respects. For one, Levine emphasises the way Dickens's detective mystery withholds knowledge of how characters are unsuspectingly networked through social and material systems, only gradually connecting the dots through suspense to create a narrative experience of 'indefinitely expanding processes of interconnectedness [...] [which] can never be grasped all at once'. ${ }^{73}$ While The Newcomes involves some (slipshod) detective work - Ethel's accidental discovery of a lost will, slipped between the pages of an old book, reshuffles the legal lines of inheritance between the branches - almost every connection between the characters, however tangential, is laid out from their introductions and can be deciphered with a little readerly mental labour. In periods of particular estrangement, members of the Newcome family are even irritated by an awareness of (and social necessity of acknowledging) their ties to each other, the exact opposite problem to the secret familial connection between Esther and Lady Dedlock. As Dames points out, in absolute 
antithesis to 'plotted suspense', the novel's 'lack of forward-directed plot' in fact led critics to complain of Thackeray's 'loitering, be it ever so humorously, philosophically, picturesquely' in the webbing of his character's intersecting lives. ${ }^{74}$

For another, if Levine identifies Dickens's key interest in the 'replaceability' of abstract family positions, marital 'nodes' in Thackeray's novels cannot be 'endlessly emptied and refilled' but replaced precisely once, and only with significant emotional consequence. ${ }^{75}$ Unlike Mrs Badger (many Thackerayan characters remarry, but none marry three times) and unlike 'Esther's two husbands, one of whom replaces himself and his house with another husband and another house in one of [Bleak House's] most unsettling moments, ${ }^{76}$ The Newcomes' significant marriages are always explicitly unsettled, either by the failure of a first love, the death of a previous spouse, or already-present (if unnoticed) signs of illness; characters either marry in conditions of compromise, or share love in conditions that compromise their ability to love again. Much as the original Thomas Newcome returns to his village to marry his first wife after her 'pale face $[\ldots]$ had grown older and paler with long waiting' ( $N C$ I 8 ), as George Levine has argued, Thackeray's characters only ever marry after 'it is too late for passion':

The narratives carefully enfold passion in layers of irony and of time that diminish passion and transform it into self-consciousness [...] In [Thackeray's] four best novels, Dobbin gets Amelia only when he has discovered the vanity of her selfishness; Esmond gets not the beautiful and sexually vital Beatrix, but her mature mother; Pen gets neither Fotheringay, nor Blanche, but a saccharine Laura [...] and we bestow Ethel on Clive only after she has outgrown her youthful energy, and he has gone through the embittering experience of a loveless marriage. ${ }^{77}$

Where for Dickens the effect of time on networks seems to be one of indefinite expansion, creating or revealing new connections to increasingly far-flung people and places, for Thackeray time degrades connectivity, beginning with a more or less fully available picture of social ties before tapering or sealing off the ability of individuals to make new relations. Read this way, the choice between two partners that confronts each character in The Newcomes is difficult not only as a moral choice between love and convenience but also because of the inevitable wear-and-tear in replacing one relationship with another - all of the new generation have problems detaching from previous partners even after they have been married to others, which in Clara's case eventuates in actual infidelity with Belsize. In Thackeray's novel, it is not only how the world is networked 
(the variety, quantity, or reach of our social ties) that is being represented and scrutinised, but also how it feels to be connected to others, an experience far from the clean slotting together of compatible connections and nodes.

\section{Indiscretion or Sentimentalism}

If a central motif of The Newcomes is the way in which characters are stuck with each other, unable to let go of their past connections, the novel also uses the social network of these characters to obsessively retrace its connections with an intertextual past. As almost all of Thackeray's critics have noted, one of the consistent habits of his oeuvre is what Chesterton deplored as an 'act of sentimentalism': the revisiting of old characters in new novels. Familiar names and faces from previous novels not only reappear, but are revealed as tangentially connected to the social world of the new work, as mutual friends or schoolmates or distant relatives: Lawrence Zygmunt, who traces the practice back to Thackeray's early journalistic career, describes the 'extraordinary tangle of bickering, overlapping links among his fictional works [...] Thackeray piles up interconnected characters and plots to produce a messy, confusing, picaresque narrative expanse'. ${ }^{78}$ For example, Arthur Pendennis is both an active character and the narrator of The Newcomes (both a friend of the family and its chronicler), whose continued life from The History of Pendennis takes place in the margins of this novel and in the later Adventures of Philip. At a party thrown by the Colonel (where Pen is also present), an initially unnamed gentleman strikes up a conversation with Clive:

'I knew your father in India', said the gentleman to [Clive]; 'there is not a more gallant or respected officer in that service. I have a boy too, a stepson, who has just gone into the army; he is older than you, he was born at the end of the Waterloo year, and so was a great friend of his and mine, who was at your school, Sir Rawdon Crawley'.

'He was in Gown Boys, I know', says the boy; 'succeeded his uncle Pitt, fourth Baronet. I don't know how his mother - her who wrote the hymns, you know, and goes to Mr. Honeyman's chapel - comes to be Rebecca, Lady Crawley. His father, Colonel Rawdon Crawley, died at Coventry Island, in August, I82-, and his uncle, Sir Pitt, not till September here. I remember, we used to talk about it at Grey Friars[.]' ( $N C_{\text {172-73) }}$

'How d'you do, Dobbin?' (I74) the Colonel later greets him, providing a redundant confirmation of recognition, given the extent and exactness to which Clive and Dobbin's conversation has mapped out every other major 
character of Vanity Fair. But redundancy is also very much the point of the passage, designed for both characters and readers to reminisce ('I remember, we used to talk about it'), specifically invoking both Vanity Fair's critically lauded Waterloo chapter and the continued pretensions of Thackeray's 'famous little Becky Puppet'. ${ }^{79}$ If Middlemarch's famous check on its own favouritism - 'but why always Dorothea?' - is for Gage McWeeny 'an Eliotic version of the question posed by any realist novel intent on broad social description', the Thackerayan version of this question - why Becky, again? - is the antithesis of both Eliot and Dickens's concerns, evoking not a 'broad' but narrow world in which everybody knows the same old people. ${ }^{80}$

The novel's fictional social network extends beyond the borders of the individual text; at the same time, its connections withdraw and fixate on the familiar, on first loves and former protagonists. Such episodes of intertextual reminiscence therefore reproduce, on the level of literary experience and form (reviving characters, revisiting locations, retelling narratives), the social experience being described on the level of plot (first loves, second marriages, widowhood). Rather than Chesterton's sense that such references damage the original work by attaching unnecessary 'after-words and appendices', or Zygmunt's argument that they represent 'isolated vignettes [which] seem largely an indulgence in characters of whom Thackeray was fond, allowable chiefly because loyal readers will recognize them', the novel evokes readerly fondness, loyalty, and recognition to simulate the feeling of being entangled in the same attachments as its characters. ${ }^{8 \mathrm{I}}$

For the character of Mrs Mackenzie, a lively Scottish widow with a young, unmarried daughter, there is especially little difference between what Zygmunt terms the 'practical' narratives of the novel's plot and the 'Extraneous' anecdotes of continuation. ${ }^{82}$ In 'setting her cap' at Clive and the Colonel, seemingly unconcerned in which combination their families are joined - 'Should you like a stepmother, Mr. Clive', one friend teases, 'or should you prefer a wife?' (NC 285) - Mrs Mackenzie ultimately secures a match by pushing Rosie to win over the Colonel's fatherly love, who in turn persuades Clive to marry his chosen daughter-in-law. This circuitous solution comes after Mrs Mackenzie's abortive attempts to persuade Clive through Rosie alone, and (the novel implies) trying for the Colonel herself. 'If she tried she failed', writes Pendennis, recounting her private impressions to him:

She said to me, 'Colonel Newcome has had some great passion, once upon a time, I am sure of that, and has no more heart to give away [...] You see 
tragedies in some people's faces. I recollect when we were in Coventry Island - there was a chaplain there - a very good man - a Mr. Bell, and married to a pretty little woman who died. The first day I saw him I said, 'I know that man has had a great grief in life. I am sure he left his heart in England[']. (286)

Modelled by Thackeray's own admission from his 'she-devil of a motherin-law', Mrs Mackenzie is not often portrayed with much sympathy in the novel. ${ }^{83}$ In this passage, however, Pendennis allows her a lengthy testimony that speaks to her effectiveness in the role of (as the novel calls her) 'the Campaigner' (74I), a satirical title with an implicit significance given the parallel plot in which Barnes loses his campaign for parliamentary reelection. While Barnes takes voters' loyalties for granted, and is disastrously accused of not recognising his own illegitimate children, 'the Campaigner' accurately intuits what readers already know as the Colonel's backstory (his failed relationship with Mademoiselle du Blois) and cannily reroutes her strategy through his abundant love for children, and Clive's love for him, to marry off Rosie. Where Barnes's failure arises from his blindness to the ties that organise society and the novel, Mrs Mackenzie's success at achieving her ends (whatever we may think of them) is rooted in a keen perception of their dynamics.

More than simple social aptitude, however, the widow's canny acuity for navigating the Newcomes' family network also has an uncanny, intertextual dimension. For example, she is again accurate in ascertaining that the chaplain 'Mr. Bell [...] has had a great grief in life' lingering from his life in England, over and above his marriage to the 'pretty little woman who died' (NC 286) in the colonial outpost of Coventry Island. These not at all straightforward conjectures about the history of Mr Bell in fact retell the pre-narrative to The History of Pendennis: Bell shared a doomed first love with Pendennis's mother, who agrees to raise his daughter after his own early death. (Mrs Mackenzie seems unaware that Pendennis, to whom she tells this story, grew up with and is now married to Laura Bell.) In another recollection from Coventry Island, she also recalls 'poor dear Sir Rawdon Crawley', Becky's husband-in-exile, and continues to follow their family narrative as 'I saw his dear boy [Becky's son] was gazetted to a lieutenant-colonelcy in the Guards last week' (283). Much as the challenge of 'why always Dorothea?' evokes the counterfactual possibility of 'a novel with a nearly unbounded factual field of characters [...] a vast shadow Middlemarch', George Levine has argued that Thackeray's 'constant allusions to and introductions of characters from other novels [...] imply both the artificial closure of any single narrative, and the proximity of other 
equally important novels while any particular narrative is going on'. ${ }^{84}$ What Thackeray might share with other realist novelists is a dissatisfaction with the limits of the novel form for a full representation of the social; where they differ is in the scope and aim of representation.

If Mrs Mackenzie embodies this dissatisfaction by habitually wandering away from the central plot of The Newcomes and into the physical 'proximity' of other lives and stories, it is always Thackeray's previous fictions that are revealed as skirting the boundaries of the present narrative. Rather than a realist and socially inclusive ambition to democratise the scope of representation, The Newcomes opens up its narrative for a certain social exclusivity, to let in an alumni's club of fictional characters. Put otherwise, intertextuality for Mrs Mackenzie is not so much about all the 'equally important novels' (that is, all the unrepresented life stories) out there as those like Dobbin, Bell, Rawdon, and Pen who are awkwardly still here:

You gentlemen who write books, Mr. Pendennis, and stop at the third volume, know very well that the real story often begins afterwards. My third volume ended when I was sixteen, and was married to my poor husband. Do you think all our adventures ended then, and that we lived happily ever after? ( $N C$ 286)

Her speech, continuing from her analysis of men who have 'no more heart to give away' (286), moves from unknowingly intertextual examples of lost or disappointed love to an analogy of intertextuality as the experience of married life or widowhood. Like Dobbin, Becky, or Pen, Thackeray's widows and widowers insist on continuing as characters beyond the conventional limits of the marriage plot, and analogously, on being emotionally welded to particular partners even after the relationship's end. Just as she understands the Colonel's story as having occurred 'once upon a time' (286), Mrs Mackenzie's (somewhat) continued loyalty to her former spouse and her (metaphorically) intertextual life after 'my third volume ended when I was sixteen' resists both social and literary forms of living 'happily ever after'. Directing her comments towards Pen as the representative of a professional class, she is unaware of his purported authorship of The Newcomes itself, and of her own place as a character within it nevertheless, Mrs Mackenzie instinctively represents her life and those of others as fictions that outgrow the boundaries of their texts.

The messy, extraneous, seemingly redundant references that connect together Thackeray's long novels embody an experience of fiction as being more persistent than the novel form allows, if nonetheless dependent on the novel as a medium. Much the same way, Thackeray's characters cling 
determinedly and often tragically to lost persons and pasts. The Newcomes, a novel which draws this analogy explicitly through Mrs Mackenzie and implicitly throughout, is morally pitched against the heartlessness of 'replaceability': Clive, trying to love his second choice; Clara and Ethel's families, negotiating their affections on the marriage market; Mrs Mackenzie, happy to be either widow or wife, stepmother or mother-inlaw; and the novel form, occasionally demanding we exchange one set of characters for another. In Ruskin's (admittedly melodramatic) view, the innocuous act of finishing a novel and beginning a new one is a deeply unnatural and Mrs Badger-like act of exchanging one set of emotional investments for another. As Thackeray's 'Proposals' protest on the insensitivity of the marriage plot, 'Do we take leave of our friends, or cease to have an interest in them, the moment they drive off in the chaise and the wedding-déjeûné is over? ${ }^{85}$ Similarly, as Ruskin argues, novelists inflict a type of emotional violence on readers with their endings, by 'shifting the scenes of fate as if they were lantern slides' (NE 605). If relationships do sometimes come to satisfying conclusions, Thackeray and Ruskin point out that this other sense of closure rarely synchronises with 'the conventionally established limits', where the pages of the novel run out; the continued attachment of our fictional 'interest' or 'affections' forms an alternative structure that (like widowhood in the marriage market) fit poorly into form and format.

\section{Closing Lines}

This sense of bad fit is most visible in The Newcomes's ending, where the narrative must self-consciously cut off while the lives it depicts continue. As James famously argued in the preface to Roderick Hudson, relations and narratives structure each other: in his elegant formulation, 'relations stop nowhere, and the exquisite problem of the artist is eternally but to draw, by a geometry of his own, the circle within which they shall happily appear to do so'. ${ }^{86}$ Novels like The Newcomes demonstrate how this circle is not only shaped by the internal structure of relations between characters, or the narrative form that rounds them off, but also acted upon by the inelegant pull of metaleptic relations - for example by the demand to 'stay long enough with people I like' ( $N E$ 605), or as Chesterton terms it, by an inexcusable 'sentimentalism'. ${ }^{87}$ Yet even as such forces drag out the Jamesian circle into a looser and baggier shape, as Caroline Levine points out, the form of the network ultimately 'runs up against the limits of [the novel's] capacity for representation', ${ }^{88}$ 
a capacity limit to which Thackeray draws emphatic attention in his abrupt conclusion to The Newcomes:

Two years ago, walking with my children in some pleasant fields, near to Berne in Switzerland, I strayed from them into a little wood; and, coming out of it presently, told them how the story had been revealed to me somehow, which for three-and-twenty months the reader has been pleased to follow. As I write the last line with a rather sad heart, Pendennis and Laura, and Ethel and Clive, fade away into Fable-land. I hardly know whether they are not true: whether they do not live near us somewhere. They were alive, and I heard their voices, but five minutes since was touched by their grief. And have we parted with them here on a sudden, and without so much as a shake of the hand? Is yonder line ( --$)$ which I drew with my own pen, a barrier between me and Hades as it were, across which I can see those figures retreating and only dimly glimmering? (NC 1007)

Three lines mark the end of the novel: the 'last line' of narrative text Thackeray writes (describing the Colonel's death), the printed 'line ( - - )' that Thackeray draws (and then miniaturises in parentheses) to separate Pendennis's narration from his direct authorial voice, and finally the 'barrier' between reality and the 'Fable-land' or 'Hades' (I007) of fiction. Media scholars Keren Eyal and Jonathan Cohen have used the term 'parasocial breakup' to refer to 'the termination of imaginary relationships' in their study of viewer reactions to the end of the decade-long television serial Friends, an event they theorise as compatible with 'premises regarding relational dissolution' with real individuals. ${ }^{89}$ Thackeray's ending seems to register a similar phenomenon, conflating a 'sudden' narratological discontinuity with an emotional break from the 'grief of living characters, contrasting the 'three-and-twenty months' of serialisation with the difference 'five minutes' makes. Even for a novel where characters like Pendennis and Mrs Mackenzie make a point of surviving beyond their 'third volume', such an ending deliberately cuts off the inter- and extratextual relationships the novel so carefully maintained, emblematised by the refusal of a final gesture of metaleptic social connection - a handshake between author and character.

Thackeray could not help but be aware, as Brontë and Trollope were, of how literary works eventually demand an end to fiction. Just over a year before his death, in a touching essay entitled 'De Finibus (On Endings)', Thackeray would return to the moment of breakup after the finish of a novel, describing in a striking echo of both his ending to The Newcomes and Brontë's hesitation at the 'threshold' of Angria: 'Those people who 
were alive half an hour since, Pendennis, Clive Newcome [...] What an odd, pleasant, humorous, melancholy feeling it is to sit in the study, alone and quiet, now all these people are gone who have been boarding and lodging with me for twenty months! ${ }^{\prime \circ}$ Much as Brontë reminisces of 'the voices, the actions, of those who peopled my thoughts by day \& not seldom stole strangely even into my dreams by night' ( $F A$ 3 I 4), Thackeray recalls in mock frustration how characters have 'interrupted my rest [...] thrust themselves upon me when I was ill, or wished to be idle'. ${ }^{\mathrm{I}}$ Just as Trollope asserts how 'the voices of the people [of Barset] are known to my ears' ( $L C B$ 728), Thackeray claims 'with respect to the personages introduced into your humble servant's fables, I know the people utterly I know the sound of their voices'. ${ }^{92}$ The reality and force of Thackeray's relationship with his own fictions lead him even to the psychological, to suspect that as 'Madmen, you know, see visions, hold conversations with, even draw the likeness of, people invisible to you and me. Is this making of people out of fancy madness? and are novel-writers at all entitled to straitwaistcoats?' ${ }^{3} 3$ Yet it is not the potential madness of fiction-making (about which he is largely facetious) which necessitates its end, but the much more banal objections of literary convention and criticism. 'My good friends', Thackeray writes, speaking to Pendennis, Clive, and Philip, 'some folks are utterly tired of you, and say',

'What a poverty of friends the man has! He is always asking us to meet those Pendennises, Newcomes, and so forth. Why does he not introduce us to some new characters?['] ${ }^{94}$

Through the imagined critic, Thackeray puts into explicit words the habit for which Brontë and Trollope also apologised, for staying among one set of characters 'too long by my love of old friendships' ( $L C B$ 728). But perhaps more revealing than the criticism Thackeray imagines for himself is the sense in which he conceives of the novel as a meeting between character, author, and reader as mutual 'friends' - such that a staleness in subject becomes a matter of bad social etiquette, always reintroducing us to his favourite families.

Readers like Barter are proof that, even if Thackeray were repeating a contemporary perception of his work, his novels nonetheless appeal to the appetite for a persistent fictional world. Representations of characters who 'vanish in an instant into the regions of Praeterita' (NE 605), or 'fade away into Fable-land' ( $N C$ I007), or readers who go 'into a distant country' ( $F A$ 3I4) or must 'take our last farewell of Barset' ( $L C B$ 727), express the traumatic separation that awaits at the borders of literary form, where 
character and reader must part; but they also identify the origins of fictional character in the realm of the subjective imaginary. Maia McAleavey has noted that Coventry Island, a colonial outpost without a real-world referent which Thackeray's novels continually reference but never depict, exemplifies Edward Said's characterisation of the colonies in major Victorian novels as 'territories [...] available for use, at will, at the novelist's discretion, usually for relatively simple purposes such as immigration, fortune, or exile'. ${ }^{95}$ Notoriously, soon after their removal there, an unspecified 'island fever' kills off any character Thackeray needs dead, like Rawdon Crawley and Arthur Bell, news of whom return to the novel as distant correspondence months after the fact. Mrs Mackenzie, however, uses the island as a nexus of connections to Vanity Fair and Pendennis; rather than a dumping ground of plot, Coventry Island could be redescribed as a unified storage space for fictions that no longer fit within the limits of representation or the literary work, or as a shared afterlife for Thackeray's finished narratives. Its availability throughout Thackeray's novels helps not only to dispose of narratives but also tie them together, drawing old and new characters closer to each other even as a distant reference point. Coventry Island undeniably represents a kind of narratological imperialism, an imagined space carved out to be 'available for use, at will, at the novelist's discretion', but its usefulness - like that of all fictional 'territories' - accommodates a range of authorial desires besides narrative and ideological convenience, including that longing for continuation which Chesterton dismissed as a novelist's 'indiscretion'. ${ }^{96}$

Locations such as Grey Friars and Coventry Island, where threads from across Thackeray's multiple novels converge and characters seem to exist in continual, intertextual simultaneity, envision within the narrative an ideal of fiction's survival beyond the literary work. In a rare moment of distinction between the historical and fictional schools of her anthology, Barter's introduction admits that 'In I 872 the Charterhouse school was, for sanitary and other reasons, removed to Godalming. But for readers of Thackeray the old Grey Friars will always stand in the heart of London city' [...] and will always be peopled by the creations of his brain'. ${ }^{97}$ Thackeray's novels very deliberately provide familiar spaces that survive each individual text, which can 'be peopled' by characters one may want to keep imagining after the story's end. 'I hardly know [...] whether they do not live near us somewhere', he writes of Ethel and Clive, Laura and Pendennis - who for Barter could be as close as central London - and ultimately ends his afterword to The Newcomes by detaching the fictional 
from the literary, by gesturing to the greater 'Fable-land' lying beyond literature:

But for you, dear friend, it is as you like. You may settle your Fable-land in your own fashion. Anything you like happens in Fable-land [...] Friendly reader! may you and the author meet there on some future day. He hopes so; as he yet keeps a lingering hold of your hand, and bids you farewell with a kind heart. ( $N C$ I007)

The 'lingering hold' which the author keeps on his reader, a gentler parting than Ethel and Clive's disappearance 'without so much as a shake of the hand', ultimately reintroduces the malleable force of reluctance and longing to the brutal 'line ( -- )' (I007) with which the afterword first opens to cut off the fictional world. ${ }^{9}{ }^{8}$ Like Brontë pausing at 'the threshold of a home' (FA 3 I 4), or Trollope seizing the reader 'affectionately by the arm' ( $L C B$ 727), these gestures acknowledge the allowances for human feeling that the aesthetic work ought to make (however apologetically) as an object which generates real experiences of familiar attachment. That we in fact exit the novel by an afterword - the kind of 'appendices' to finished work Chesterton disdained - exemplifies the lines of form stretching to meet these needs for fiction.

At the same time, Thackeray also reveals fiction to be a domain of subjective wish-fulfilment after all, where the inherent disappointment of novels can nonetheless be made 'as you like' ( $N C$ 1007). As with the sophist or the Chief Genii, this does not represent a pessimism about its reality or importance, but an exercise of its resources as a pretence to satisfy what seems materially impossible. The literary text must necessarily finish, closing out the fictional world which burgeons from within it, but it can also provide - through the examples of Grey Friars and Coventry Island an imaginative conceit of its continuation: a fantasy that its fictions are still 'out there', living on beyond sight of narrative. To acknowledge this fantasy as it simultaneously vitalises and outlives the text is to understand the novel not only as a material and literary work, but as a tool in the wider imaginative practice of fiction. Making such distinctions between the literary and the fictional offers a new perspective on the novel as a medium for fictional worlds, one which enables a critical reassessment of its value and uses in that capacity. 